\title{
A Distinct Role of Pectate Lyases in the Formation of Feeding Structures Induced by Cyst and Root-Knot Nematodes
}

\author{
K. Wieczorek, ${ }^{1}$ A. Elashry, ${ }^{2}$ M. Quentin, ${ }^{3}$ F. M. W. Grundler, ${ }^{2}$ B. Favery, ${ }^{3}$ G. J. Seifert, ${ }^{4}$ and H. Bohlmann ${ }^{1}$ \\ ${ }^{1}$ Division of Plant Protection, Department of Crop Sciences, University of Natural Resources and Life Sciences, Konrad- \\ Lorenz Straße 24, A-3430 Tulln, Austria; ${ }^{2}$ Institute of Crop Science and Resource Conservation, Department Molecular \\ Phytomedicine, University Bonn, Karlrobert-Kreiten-Str. 13, D-53115 Bonn, Germany; ${ }^{3}$ nstitut Sophia Agrobiotech UMR \\ INRA 1355-CNRS 7254-Université de Nice Sophia Antipolis, F-06903, Sophia Antipolis, France; ${ }^{4}$ Department of Applied \\ Genetics and Cell Biology, University of Natural Resources and Life Sciences, Muthgasse 18, A-1190 Vienna
}

Submitted 8 January 2014. Accepted 23 May 2014.

Pectin in the primary plant cell wall is thought to be responsible for its porosity, charge density, and microfibril spacing and is the main component of the middle lamella. Plantparasitic nematodes secrete cell wall-degrading enzymes that macerate the plant tissue, facilitating the penetration and migration within the roots. In sedentary endoparasitic nematodes, these enzymes are released only during the migration of infective juveniles through the root. Later, nematodes manipulate the expression of host plant genes, including various cell wall enzymes, in order to induce specific feeding sites. In this study, we investigated expression of two Arabidopsis pectate lyase-like genes (PLL), PLL18 (At3g27400) and PLL19 (At4g24780), together with pectic epitopes with different degrees of methylesterification in both syncytia induced by the cyst nematode Heterodera schachtii and giant cells induced by the root-knot nematode Meloidogyne incognita. We confirmed upregulation of PLL18 and PLL19 in both types of feeding sites with quantitative reverse-transcriptase polymerase chain reaction (RT-PCR) and in situ RT-PCR. Furthermore, the functional analysis of mutants demonstrated the important role of both $P L L$ genes in the development and maintenance of syncytia but not giant cells. Our results show that both enzymes play distinct roles in different infected root tissues as well as during parasitism of different nematodes.

Plant-parasitic nematodes are responsible for severe crop damage worldwide. In particular, two groups, cyst nematodes (Heterodera and Globodera spp.) and root-knot nematodes (Meloidogyne spp.), cause losses in the production of a wide range of field crops which exceed \$US100 billion annually (Bird and Kaloshian 2003). The infective juveniles hatch from eggs in the soil and migrate toward the roots of the host plants. To survive and to reproduce, they establish a sophisticated nutritional interaction with the host by inducing feeding structures that serve as a source of nutrients during the entire para-

Corresponding author: K. Wieczorek;

E-mail: krzysztof.wieczorek@boku.ac.at

* The $\boldsymbol{e}$-Xtra logo stands for "electronic extra" and indicates that two supplementary figures are published online and that Figure 6 appears in color online.

(C) 2014 The American Phytopathological Society sitic process. The juveniles of cyst nematodes enter the root in the elongation zone and migrate intracellularly in search of a single cell suitable for feeding site initiation within the central cylinder. They gently pierce it with their stylet and, with the aid of secretions from the gland cells, they trigger massive changes that lead to the formation of feeding sites termed syncytia (Sijmons 1991; Wyss 1992; Wyss and Grundler 1992; Wyss and Zunke 1986). The initial cell fuses with the neighboring cells by tightly controlled cell wall degradation. Subsequently, the young syncytium continuously enlarges and more and more cells are incorporated into the feeding site that becomes a hypertrophied multinucleate large cell (Wyss and Grundler 1992). Juveniles undergo three subsequent molts, differentiate sexually, and, after fertilization by the mobile male, the female becomes a lemon-shaped cyst that is filled with eggs. In contrast, juveniles of the root-knot nematodes invade roots behind the tip and move intercellularly without damage of the root cells into the tip meristem, where they turn around and enter the central cylinder (von Mende 1997). They select a few suitable cells and stimulate them to develop into large multinucleate giant cells through several rounds of repeated nuclear divisions without complete cytokinesis (Caillaud et al. 2008). Similar to cyst nematodes, the juveniles molt three times but the reproduction in most species is parthenogenetic and eggs are deposited outside the female body (Atkinson et al. 1996).

Cell wall modifications play an important role during nematode feeding site formation. On the one hand, they include increased extension and massive wall thickening as well as formation of ingrowths in syncytia and giant cells (Siddique et al. 2012; Wieczorek et al. 2006). On the other hand, extensive cell wall degradation occurs in syncytia (Goellner et al. 2001; Sukno et al. 2006; Wieczorek et al. 2008). In contrast to the relatively detailed data on the migration stage, knowledge concerning the cell wall-modifying enzymes secreted by the nematode during the sedentary stage is still very limited. It was shown that cellulases are expressed in adult females of rootknot nematodes (Rosso et al. 1999); however, whether they have a function in giant cells remains unknown. More recently, Hewezi and associates (2008) showed that a cellulose-binding domain protein secreted by the juveniles of the sugar beet nematode Heterodera schachtii interacts with a plant pectin methyl esterase (PME) that gets activated and may facilitate nematode parasitism. Much more data are available on wall alterations in nematode feeding sites caused by the cell wall- 
modifying, -degrading, and -biosynthetic enzymes of plant origin that are specifically activated during nematode parasitism; however, their exact role remains to be elucidated. Glucanases (Goellner et al. 2001; Sukno et al. 2006; Wieczorek et al. 2008), pectin acetyl esterase (PAE) (Vercauteren et al. 2002), expansins (Fudali et al. 2008; Jammes et al. 2005; Wieczorek et al. 2006), pectate lyases (PL) (Jammes et al. 2005; Tucker et al. 2007), and cellulose synthases (Hudson 2008) are only some of the well-described examples (Davis et al. 2011; Sobczak et al. 2011).

The primary cell wall comprises approximately $10 \%$ proteins and $90 \%$ polysaccharides. In addition to cellulose and hemicellulose, one of the main components of the primary plant cell wall is pectin (McNeil et al. 1984). This polymer network is thought to be responsible for wall porosity, charge density, and microfibril spacing. It is the main component of the middle lamella between two adjacent plant cells and contributes to intercellular adhesion and controlled separation. Pectin is synthetized in the Golgi apparatus in highly methyl esterified form as three different polysaccharides: rhamnogalacturonan I, rhamnogalacturonan II, and homogalacturonan (HG), whose backbone consists of $\alpha$-D-galacturonic acid residues. After the deposition of pectin in the apoplast, PME selectively remove the methyl groups. The extent and pattern of methylation affect the functional characteristics of pectin which, in turn, has an influence on the strength of the cell wall and the accessibility to pectin degrading enzymes (Atmodjo et al. 2013). Pectin is present in syncytial cell walls (Sobczak 1996) and, recently, it was shown by immunochemistry that the pectic $\mathrm{HG}$ in walls of mature syncytia induced by $H$. schachtii occurs in a highly methyl-esterified form (Davies et al. 2012). Demethylation of pectin driven by methyl esterases is a prerequisite for its digestion by polygalacturonases or PL (Knox 2002). Polygalacturonases (E.C. 3.2.1.15) hydrolyze the linkage between galacturonic acids in unmethylated HG. PL are (1-4)- $\alpha$-D-galacturonan lyases (EC 4.2.2.2) and catalyze the eliminative cleavage of unmethylated pectin. They are secreted by a variety of plant pathogens, including plant-parasitic nematodes (Danchin et al. 2010; Doyle et al. 2002; Huang et al. 2005; Kudla et al. 2007; Popeijus et al. 2000; Vanholme et al. 2007), and play a crucial role in the maceration of plant tissues during nematode migration through the root tissue. The large number of PECTATE LYASE-LIKE sequences $(P L L)$ in plant genomes (e.g., 26 isoforms in Arabidopsis) suggests an important role for these enzymes in various plant developmental processes such as stamen abscission or cortical cell separation during the emergence of the lateral root (Cai and Lashbrook 2008; Palusa et al. 2007; Sun and van Nocker 2010; Swarup et al. 2008).

In this work, we analyzed the role of two Arabidopsis $P L L$ genes, PLL18 (At3g27400) and PLL19 (At4g24780), in parasitism of cyst and root-knot nematodes. Both genes have been previously shown to be upregulated in syncytia induced by $H$. schachtii and giant cells induced by Meloidogyne incognita. Using quantitative reverse-transcriptase polymerase chain reaction (qRT-PCR), $\beta$-glucuronidase (GUS) assays, and in situ
RT-PCR, we confirmed their elevated expression in both feeding sites. An analysis of mutants showed fewer $H$. schachtii females attached to smaller syncytia but no significant effects on development of $M$. incognita and their feeding sites. Thus, while loss of neither gene has an effect on the development of giant cells, they play an important role during the formation of syncytia and development of cyst nematodes.

\section{RESULTS}

\section{PLL18 and PLL19 are upregulated in root tissue infected by cyst and root-knot nematodes.}

Previous GeneChip and microarray studies showed that PLL18 (At3g27400) and PLL19 (At4g24780) were among the most strongly upregulated genes in syncytia of $H$. schachtii (Szakasits et al. 2009) and were specifically upregulated in $M$. incognita-induced galls (Jammes et al. 2005). We confirmed these results by qRT-PCR (Table 1) for root segments containing the feeding sites induced by $H$. schachtii at 5 and 15 days after inoculation (dai). PLL18 showed much higher expression in these tissues when compared with the GeneChip (approximately four and three times higher in syncytia at 5 and 15 dai, respectively). qRT-PCR performed by Jammes and associates (2005) validated upregulation of PLL18 and PLL19 in galls at 7,14 , and 21 dai (Table 1).

In the next step, we analyzed the expression pattern of PLL18 and PLL19 in roots infected with H. schachtii and M. incognita using promPLL18::GUS and promPLL19::GUS lines. The PLL18 promoter was active in syncytia at 5 and 15 dai (Fig. 1A and B). Specific GUS staining was also observed in galls at 7 dai (Fig. 1C) as well as at 14 dai (Fig. 1D). Only weak GUS activity was detected in galls at 21 dai (Fig. 1E). In the uninfected main root, promPLL18-driven GUS expression could not be detected (Fig. 1F), which is in line with the root expression shown with the Root Visualization Expression Map (Supplementary Fig. S1). In infected promPLL19::GUS plants, strong GUS induction in syncytia at 5 and 15 dai (Fig. $1 \mathrm{G}$ and $\mathrm{H})$ was observed, with 15 dai showing considerably stronger staining. In contrast, in the uninfected main root, GUS expression was visible throughout the entire root vasculature (Fig. 1L), which is in line with the expression pattern of PLL19 from the Root Visualization Expression Map. During interaction with $M$. incognita, activity of promPLL19 was detected in galls at 7 and 14 dai (Fig. 1I and J), whereas there was only very little staining in galls at 21 dai (Fig. 1K).

In order to directly localize the transcripts of both $P L L$ at the single-cell level, we performed in situ RT-PCR experiments on 15-dai syncytia and 14-dai gall sections. Clear and strong signals of PLL 18 transcripts were visible within the syncytium as well as in the surrounding vascular tissue (Fig. 2A). In giant cells and in the surrounding gall tissue at 14 dai, clear signals of PLL18 transcripts were found (Fig. 2C). As expected, we observed a lack of the PLL18 signal in the uninfected root tissue (Fig. 2I). Clear signals of PLL19 mRNA were observed within the syncytium (Fig. 2E) whereas, in the surrounding vascular tissue, the staining was rather weak. In contrast, PLL19

Table 1. Summary of GeneChip, microarray, and quantitative reverse-transcriptase polymerase chain reaction (qRT-PCR) data obtained for pectate lyase-like (PLL) genes PLL18 and PLL19 with syncytia at 5 and 15 days after inoculation (dai) and giant-cell-enriched root tissue at 7, 14, and 21 dai

\begin{tabular}{|c|c|c|c|c|c|c|c|c|c|}
\hline \multirow[b]{2}{*}{ Genes } & \multicolumn{3}{|c|}{ Heterodera schachtii } & \multicolumn{6}{|c|}{ Meloidogyne incognita } \\
\hline & $\begin{array}{c}\text { Affymetrix } 5 \\
\text { and } 15 \text { dai }\end{array}$ & $\begin{array}{c}\text { qPCR } \\
5 \text { dai }\end{array}$ & $\begin{array}{l}\text { qPCR } \\
15 \text { dai }\end{array}$ & $\begin{array}{c}\text { CATMA } \\
7 \text { dai }\end{array}$ & $\begin{array}{l}\text { qPCR } \\
7 \text { dai }\end{array}$ & $\begin{array}{c}\text { CATMA } \\
14 \text { dai }\end{array}$ & $\begin{array}{l}\text { qPCR } \\
14 \text { dai }\end{array}$ & $\begin{array}{c}\text { CATMA } \\
21 \text { dai }\end{array}$ & $\begin{array}{l}\text { qPCR } \\
21 \text { dai }\end{array}$ \\
\hline$\overline{\text { PLL18 }}$ & 7.30 & 26.63 & 22.89 & 0.21 & 1.91 & 1.07 & 3.95 & 1.71 & 4.26 \\
\hline PLL19 & 6.80 & 2.18 & 4.55 & 1.48 & 2.11 & 3.73 & 4.84 & 3.98 & 4.89 \\
\hline
\end{tabular}

${ }^{\mathrm{a}}$ All values are $\log _{2}$ ratios for comparisons between infected tissues and uninfected roots fragments. Affymetrix data for $H$. schachtii taken from Szakasits and associates (2009); complete Arabidopsis transcriptome microarray and qPCR data for M. incognita taken from Jammes and associates (2005). 
signals could be found in both giant cells and surrounding root cells (Fig. 2G). Uninfected roots showed PLL19 expression in the vascular tissue (Fig. 2J).

\section{$P L L 18$ and $P L L 19$ are important for development of cyst nematodes but not root-knot nematodes.}

In order to test whether the upregulation of PLL18 and PLL19 plays an important role in the development of both feeding sites and the life of the cyst and root-knot nematodes, we tested T-DNA mutant lines pll18 and pll19 (Fig. 3A) that showed a reduction in the abundance of PLL18 and PLL19 transcripts, respectively (Fig. 3B). In addition, both mutants showed clear growth phenotypes in 10-day-old plants (Fig. 4A). Compared with wild-type seedlings (Arabidopsis ecotype WS), the pll18 and pll19 lines exhibited shorter roots $(-25.8$ and $-18.1 \%$, respectively). Similarly, the rosette area of both mutants was also significantly smaller than that of the wildtype plants $(-30.8 \%$ for pll18 and $-24.4 \%$ for pll19) (Fig. 4B).

Using pll18 and pll19 mutants, we carried out nematode infection assays with $H$. schachtii and $M$. incognita. In the case of cyst nematodes, pll18 supported significantly less females per root centimeter than WS plants. The number of males and the total infection rate (both per root centimeter) remained unchanged when compared with the WS plants. In contrast, in the pll19 line, not only the number of females but also the total infection rate was significantly reduced (Fig. 5A). Further, we looked at the male/female ratio because it can give hints about the conditions within the host plant. It is known that significantly more females develop when the nutritional and environmental conditions are better than when they are not optimal for nematodes (Triantaphyllou 1973). The pll18 mutant did not exhibit a significant change in male/female ratio when com-
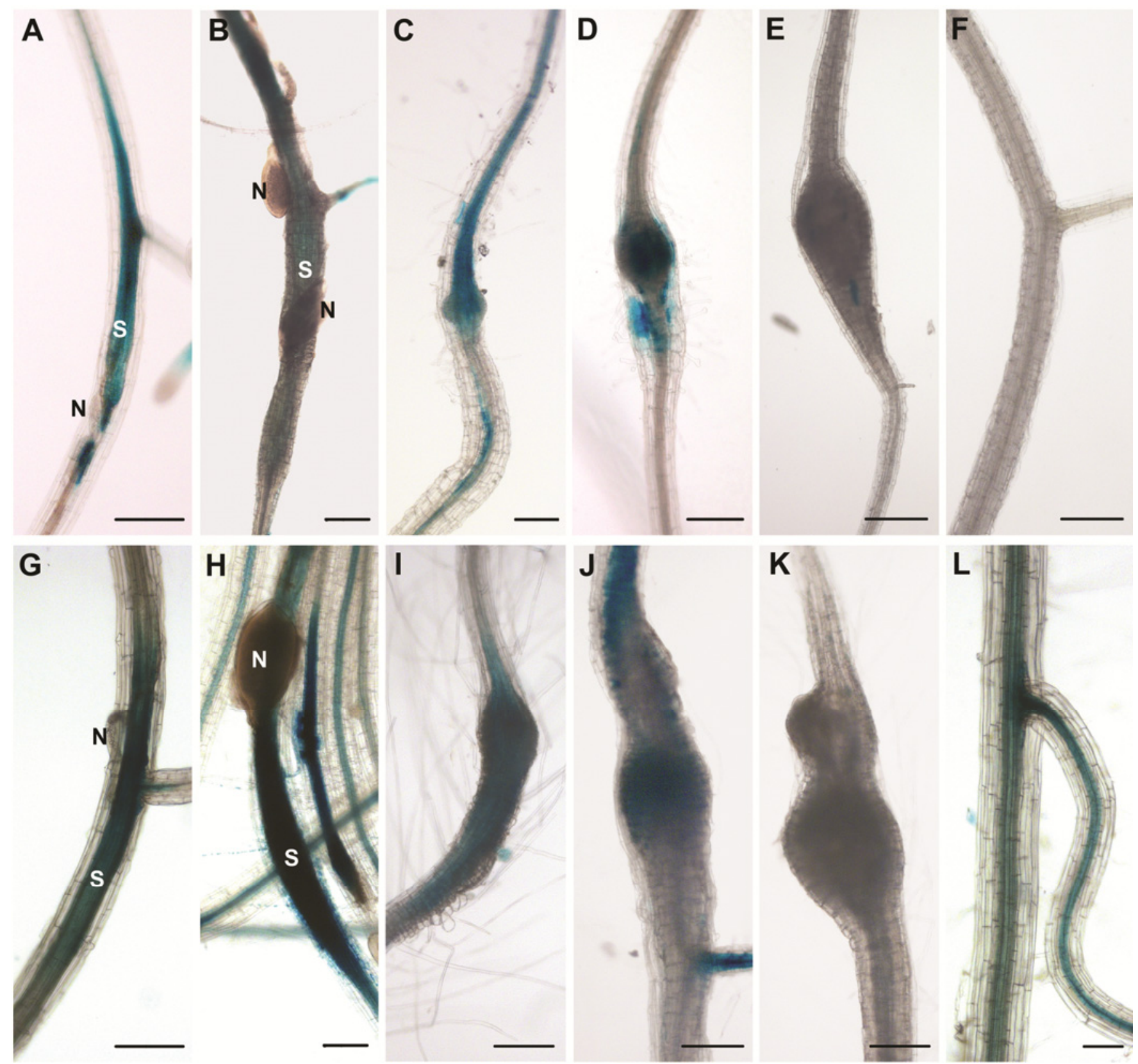

Fig. 1. Histochemical $\beta$-glucuronidase (GUS) analysis of $\mathbf{A}$ through $\mathbf{F}$, PLL18 and $\mathbf{G}$ through $\mathbf{L}$, PLL19 promoter activities during Heterodera schachtii (A and $\mathrm{B}, \mathrm{G}$ and $\mathrm{H}$ ) and Meloidogyne incognita infection (C-E and I-K). $\mathbf{A}$ and $\mathbf{G}$, syncytium at 5 days after inoculation (dai); $\mathbf{B}$ and $\mathbf{H}$, syncytium at 15 dai; $\mathbf{C}$ and $\mathbf{I}$, gall at 7 dai; $\mathbf{D}$ and $\mathbf{J}$, gall at 14 dai; $\mathbf{E}$ and $\mathbf{K}$, gall at 21 dai; and $\mathbf{F}$ and $\mathbf{L}$, uninfected main root of PLL18:GUS and PLL19:GUS, respectively. S = syncytium and $\mathrm{N}=$ nematode $($ H. schachtii). Bars $=200 \mu \mathrm{m}$. 
pared with WS, whereas this ratio was significantly increased in the case of the pll19 mutant, with more males than females developing on the roots (Fig. 5B).

We next analyzed alterations in syncytium development in the mutant lines. In the pll19 mutant, we found a significant
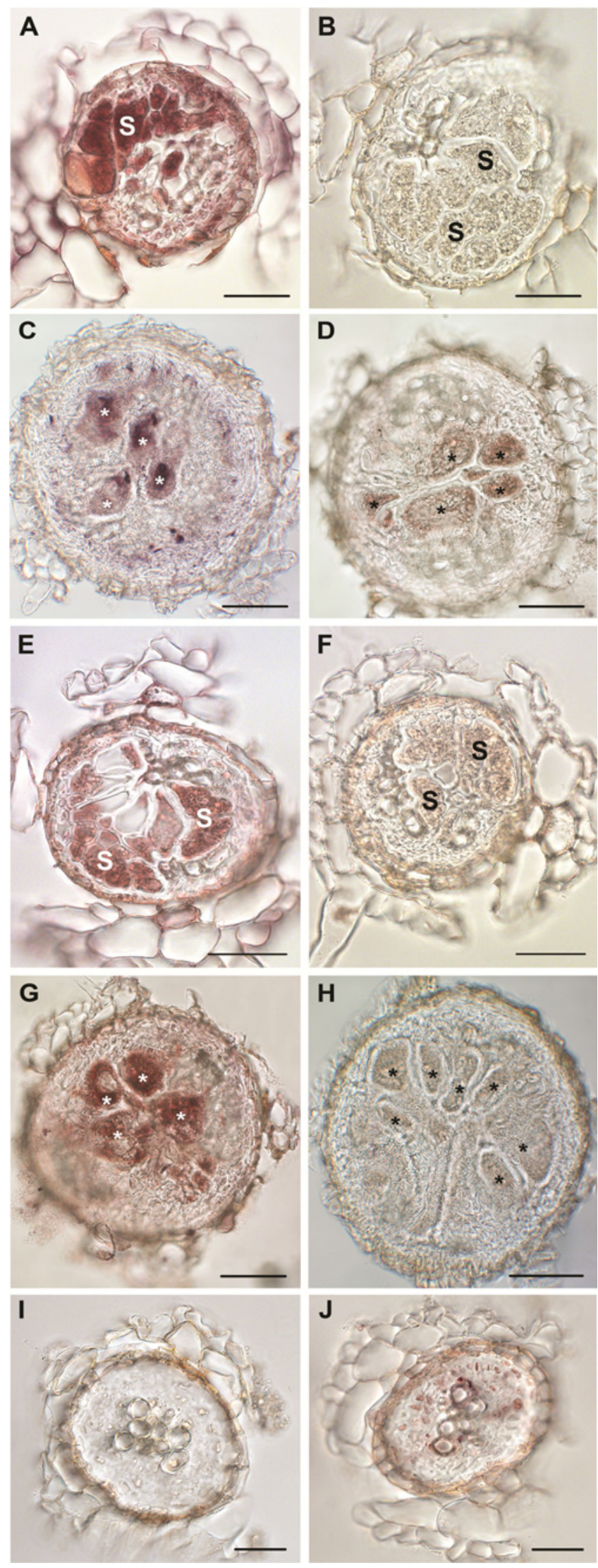

reduction in the length of the syncytia compared with WS (Fig. 5C). Syncytia developing on the line pll18, however, did not show any differences when compared with wild-type syncytia. In addition, we evaluated the number of retarded (empty), small (average cyst area $161.6 \pm 7.7 \mathrm{~mm}^{2}$ ), medium (average cyst area $336.1 \pm 6.2 \mathrm{~mm}^{2}$ ), and large (average cyst area 460.4 $\pm 5.5 \mathrm{~mm}^{2}$ ) cysts 1 month after inoculation (Fig. 6). We found considerably more retarded cysts on pll18 and pll19 mutant lines (11.7 and $16.0 \%$, respectively) when compared with the WS wild-type roots $(5.0 \%)$. Similarly, the number of small cysts was increased on both mutants compared with WS (17.1\% in WS versus 25.5 and $19.7 \%$ in pll18 and pll19, respectively). The number of medium-sized cysts was higher in WS $(30.5 \%)$ than in pll18 and pll19 lines (29.4 and $25.9 \%$, respectively). The highest percentage of large cysts was counted in roots of the WS wild-type line $(47.9 \%)$, whereas pll18 and pll19 contained less large cysts (33.3 and $38.3 \%$, respectively) (Fig. 6).

The number of lateral roots at the inoculation time influences greatly the infection rate of $M$. incognita. Hence, prior to the infection tests, we estimated the number of lateral roots in

\section{$<$}

Fig. 2. In situ reverse-transcriptase polymerase chain reaction of PLL18 and PLL19 in syncytia at 15 days after inoculation (dai) and galls at 14 dai. A, Strong signal of PLL18 mRNAs is visible in the syncytium as well as in uninfected vascular cylinder cells surrounding the feeding site. B, Control reaction for A performed without Taq polymerase on a 15-dai syncytium section. Staining is not visible in either the feeding site or surrounding cells. C, Signal for PLL18 mRNAs is visible in giant cells as well as in the gall tissue. $\mathbf{D}$, Control reaction for $\mathrm{C}$ performed without Taq polymerase on a 14-dai gall. Only unspecific brownish staining is visible. E, Strong signal of PLL19 transcripts is visible in the syncytium. Weak staining is visible in the tissue around the syncytium. F, Control reaction for $\mathrm{E}$ performed without Taq polymerase on a 15-dai syncytium section. Staining is not visible in either the feeding site or surrounding cells. G, Signal of PLL19 mRNAs is visible in giant cells at 14 dai as well as in the gall tissue. H, Control reaction for $\mathrm{G}$ performed without Taq polymerase. I, Lack of PLL18 signal in the uninfected root. J, Clear signals of PLL19 in central cylinder in the uninfected root. $\mathrm{S}=$ syncytium and stars = giant cells. Bars $=50 \mu \mathrm{m}$.

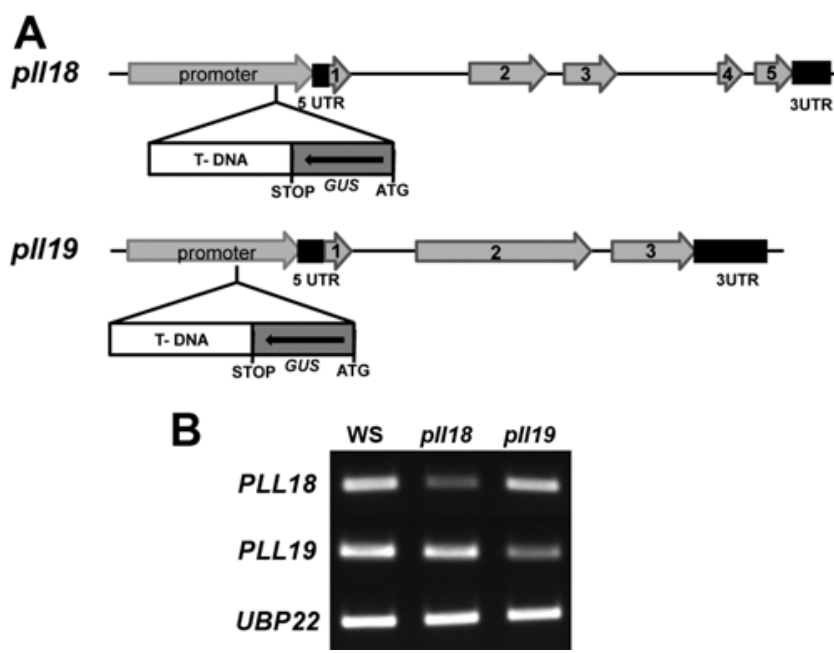

Fig. 3. T-DNA insertion mutants pll18 and pll19. A, Intron-exon structures for both genes and the position of inserted T-DNA in the promoter region of PLL18 and PLL19. B, Reverse-transcriptase polymerase chain reaction of the PLL18 and PLL19 in ecotype WS, pll18, and pll19. This analysis shows the significant reduction in the transcript abundance of PLL18 in pll18 and PLL19 in pll19 lines. Expression of PLL18 in the pll19 line as well as PLL19 in the pll18 line resembles the level of expression of both genes in the WS wild type. UBP22 was used as an internal control. 
15-day-old WS and pll18 and pll19 plants (Supplementary Fig. S2). Because there was no significant difference in the number of lateral roots between the lines (WS $=18$, pll18 $=18.4$, and pll19 = 17.1), we show all measured parameters as per plant. Results show that both mutant lines did not significantly differ from the WS wild-type line in the number of galls per plant (Fig. 7A) as well as in the number of egg masses per plant (Fig. 7B).

\section{Degree of pectin esterification in nematode-infected tissue.}

Our results showed that both $P L L$ genes are upregulated in syncytia and galls induced by $H$. schachtii and $M$. incognita, respectively, and have an important role in the development and maintenance of syncytia but not giant cells. PL are known to hydrolyze de-esterified pectin. Recently, the presence of heavily methyl-esterified pectic HG in syncytial walls at 14 dai was reported (Davies et al. 2012). Therefore, we performed immunochemistry to analyze the localization of HG epitopes corresponding to different degrees of methyl-esterification in cell walls of younger syncytia (5 dai) and giant cells ( 7 and 14 dai). For comparison with previously published results (Davies et al. 2012), 15-dai syncytia have been included. The monoclonal antibody LM19 preferentially binds to pectic HG independent of esterification whereas LM20 requires methyl-esterification to bind to HG (Verhertbruggen et al. 2009). To homogeneously reveal all unesterified pectin epitopes, we pretreated feeding site sections with sodium carbonate $\left(\mathrm{Na}_{2} \mathrm{CO}_{3}\right.$, $\mathrm{pH}$ 11.4).
Results showed that LM19 bound strongly to cell walls of the epidermis, cortex, and stele cells as well as to the walls of 5-dai syncytia, and the intensity of the signal was similar without (Fig. 8B) and with (Fig. 8C) $\mathrm{Na}_{2} \mathrm{CO}_{3}$ pretreatment. In sections of 5-dai syncytia, LM20 bound exclusively to xylem elements, whereas there was no staining in syncytial walls (Fig. 8D).

For 15-dai syncytia, we confirmed the results obtained by Davies and associates (2012) showing a weak LM19 signal in some cell walls in the stele but almost no staining in syncytial walls (Fig. 8F). As expected, after $\mathrm{Na}_{2} \mathrm{CO}_{3}$ pretreatment, LM19 detected unmethylated $\mathrm{HG}$ in the stele and syncytial cell walls at 15 dai (Fig. 8G). LM20 bound strongly to cell walls of the stele cells as well as to syncytial cell walls (Fig. 8H).

Without the $\mathrm{Na}_{2} \mathrm{CO}_{3}$ pretreatment, the detection level of LM19 in 7-dai galls was very low (Fig. 8J), whereas the pretreatment led to the higher abundance of the LM19 epitope throughout all cell walls (Fig. 8K). In 7-dai galls, LM20 bound strongly to the stele cells and walls of giant cells (Fig. 8L).

In untreated cell walls of 14-dai galls, the LM19 signal is clearly visible (Fig. $8 \mathrm{~N}$ ); however, the $\mathrm{Na}_{2} \mathrm{CO}_{3}$ pretreatment led to increased binding of LM19 throughout all cell walls (Fig. 8O). In 14-dai galls, LM20 bound strongly to the stele cells and cell walls of giant cells (Fig. 8P).

These results demonstrated that de-esterified $\mathrm{HG}$ in steles hosting syncytia as well as in syncytial cell walls was relatively more abundant at 5 than at 15 dai. In contrast to older feeding sites, highly methyl-esterified HG was not detected in younger syncytial cell walls.
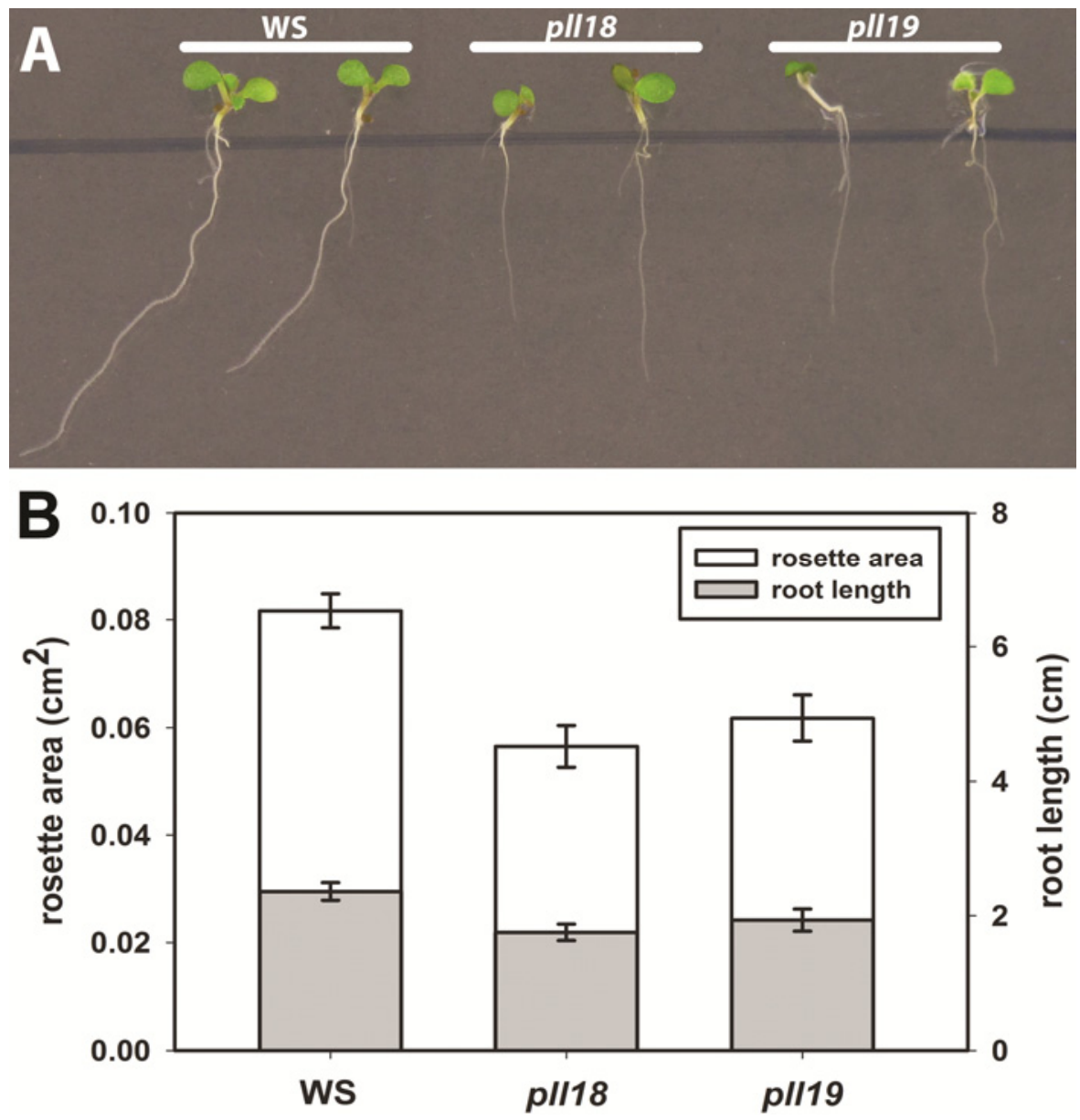

Fig. 4. Phenotype of the mutant lines pll18 and pll19 compared with wild-type seedlings (ecotype WS). A, Shoot and root phenotype of 10-day-old seedlings of WS, pll18, and pll19. B, Rosette area and root length of 10-day-old seedlings of pll18 and pll19 lines compared with the wild-type seedlings (WS). In all, 23, 24, and 29 single plants of the pll18 and pll19 lines and WS, respectively, were analyzed. Error bars show the standard errors from the mean. Asterisks represent significant differences; $P<0.05$ versus control by analysis of variance. 
De-esterified HG was detected at low levels in galls at 7 dai and at slightly larger levels at 14 dai. Highly methyl-esterified HG was abundant in walls of gall cells as well as in walls of giant cells at 7 and 14 dai.

\section{DISCUSSION}

Cell wall-digesting and -modifying enzymes play an important role in the interaction between host plants and plant-para- sitic nematodes. On the one hand, numerous recent reports showed that these enzymes are produced in specialized nematode gland cells and secreted during the parasitism process. In the case of sedentary endoparasitic nematodes, this occurs mainly during juvenile migration through the root tissue, when these enzymes play a crucial role in the maceration of the plant tissue facilitating the infection (Hewezi and Baum 2012). On the other hand, cell wall enzymes of plant origin play important roles in the establishment and maintenance of the feed-
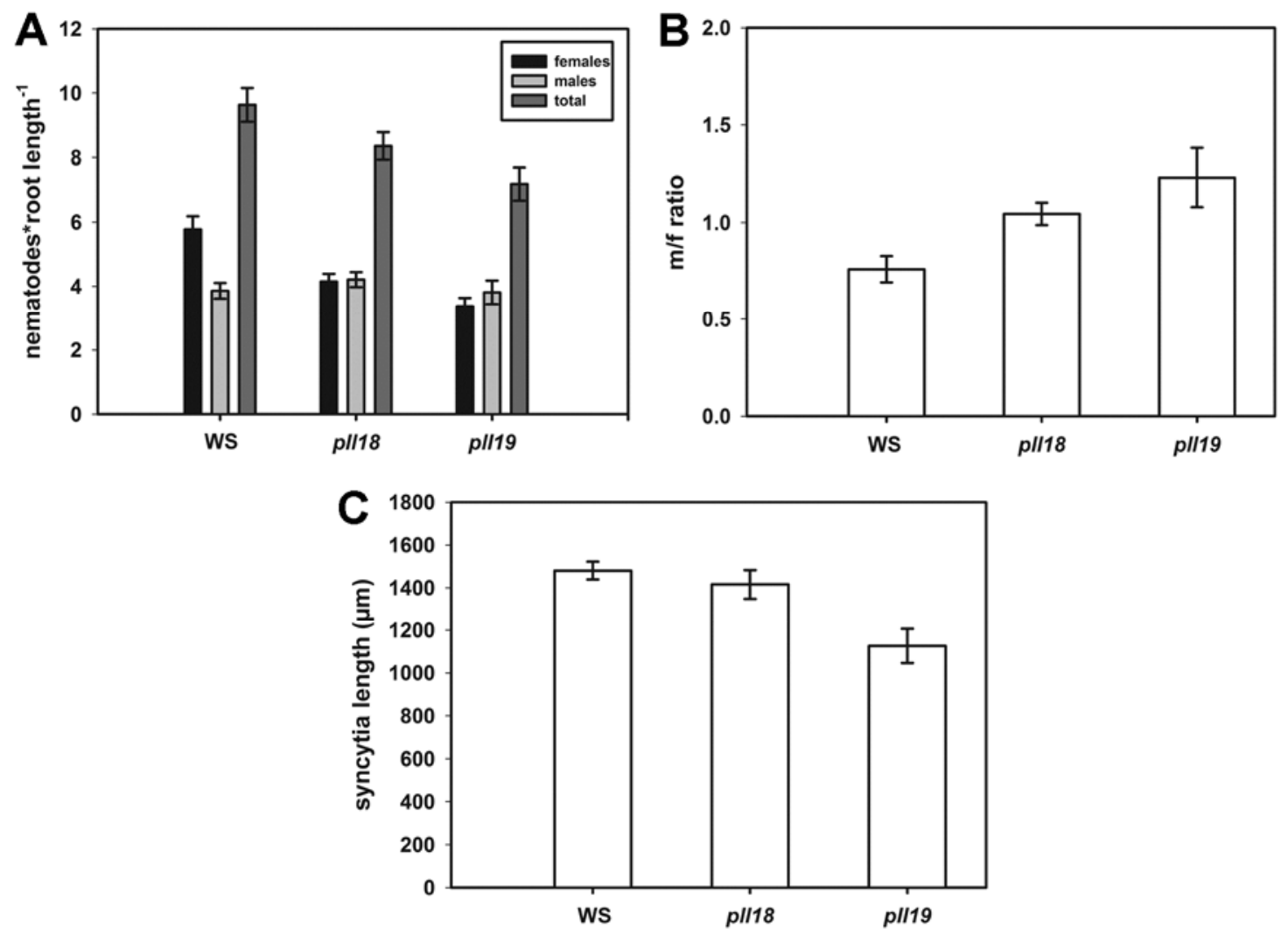

Fig. 5. Infection assay with Heterodera schachtii. A, Number of females and males and total number of nematodes per centimeter of root length of WS, pll18, and pll19 lines. Average number of plants/experiment: $\mathrm{WS}=64$, pll18 $=48$, and pll19 $=23$. B, Male/female ratio in roots of WS, pll18, and pll19 lines. C, Length of syncytia induced in roots of WS, pll18, and pll19 lines. In all, 38, 62, and 74 single syncytia developing on the pll18 and pll19 lines and ecotype WS, respectively, were measured. Error bars show the standard errors from the mean. Asterisks represent significant differences; $P<0.05$ versus control by analysis of variance.

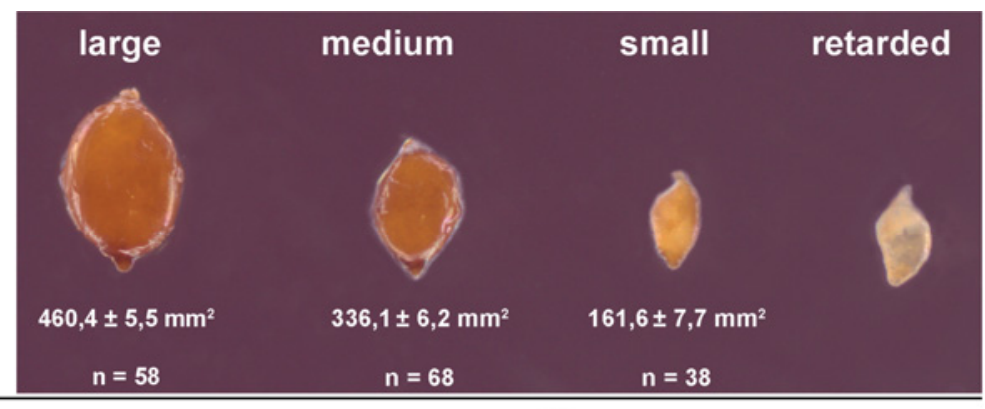

\begin{tabular}{ccccc}
\hline line & \multicolumn{4}{c}{ cysts \% } \\
\hline WS & 47.9 & 30.5 & 17.1 & 5.0 \\
pll18 & 33.3 & 29.4 & 25.5 & 11.7 \\
pll19 & 38.3 & 25.9 & 19.7 & 16.0 \\
\hline
\end{tabular}

Fig. 6. Different size classes and percentage of retarded, small, medium, and large Heterodera schachtii cysts 1 month after inoculation on roots of WS, pll18, and pll19 lines. 
ing site as well as the completion of the nematode life cycle (Goellner et al. 2001; Mitchum et al. 2004; Vercauteren et al. 2002; Wieczorek et al. 2006, 2008). Hence, successful nematode parasitism requires extensive and tightly coordinated modifications, extension, and enlargement as well as degradation of plant cell walls driven by diverse enzymes of either origin.

Pectin is one of the main plant cell-wall components in primary cell walls. For the first step of its degradation, the action of pectin esterases is required, which remove acetyl or methyl groups. This process makes the cell wall more accessible not only to pectin-degrading enzymes such as PL or polygalacturonases but also to other cell wall-modifying enzymes (Caffall and Mohnen 2009). In particular, PL, a group of enzymes that digest the unmethylated form of pectin, were shown to play an important role during many host-pathogen interactions. Most of the cell wall-penetrating plant pathogens are armed with their own PL (Payasi et al. 2009). However, there is evidence that some plant pathogens and symbionts use host $P L L$ for tissue penetration and successful infection. Vogel and associates (2002) showed that infection of Arabidopsis by the powdery mildew pathogen Erysiphe cichoracearum requires the PLL13 gene (also known as PMR6) whose mutation mediates resistance toward this pathogen. Rhizobial infection of legume plants also requires plant PL (Xie et al. 2012). In this work, we investigated the role of Arabidopsis PLL genes during the formation and maintenance of both syncytia and giant cells. According to Sun and van Nocker (2010), Arabidopsis has 26 $P L L$ that can be divided into five subfamilies. We noticed that two of these genes, PLL18 and PLL19, were among the most strongly upregulated genes in syncytia induced by $H$. schachtii (Szakasits et al. 2009) and infection sites of $M$. incognita (Jammes et al. 2005). Together with PLL15 and PLL16, they form a small group in subfamily I and have a similar expression pattern in shoots. Promoters of PLL18 and PLL19 drove GUS expression in the region of the abscission zone as well as in the region just before abscission (Sun and van Nocker 2010). In roots, however, they differ considerably because $P L L 18:: G U S$ showed only a weak staining along the axis of the primary root whereas the staining of PLL19::GUS roots was stronger and more specific during the entire root development. In nematode-infected roots, as shown by GeneChip and microarray assays, both genes are upregulated in syncytia and galls (Jammes et al. 2005; Szakasits et al. 2009). In the case of $H$. schachtii, the pure micro-aspirated content of the feeding sites was used for the GeneChip analysis, giving information about the gene expression exclusively within the syncytia. However, it does not give hints concerning gene expression in the tissue that surrounds the feeding site. Therefore, we performed a qRT-PCR analysis of root segments containing syncytia and surrounding root tissue, an analysis of promoter::
GUS lines, as well as in situ RT-PCR for both PLL. Using GUS lines, we confirmed the upregulation of both genes for syncytia at 5 and 15 dai as well as galls at 7 and 14 dai. According to microarray data, both PLL are upregulated in 21dai galls but we observed only faint staining in the infected tissue at this time point. This can be explained by the phenomenon that GUS activity generally decreases in older nematode feeding sites (Barthels et al. 1997; Puzio et al. 1998). According to qRT-PCR, PLL18 showed a considerably higher expression level when the surrounding root tissue was included for analysis compared with the transcriptome analysis (Szakasits et al. 2009). This might be due to the upregulation of PLL18 in the root tissue adjacent to the syncytium that we showed at the single-cell level with in situ RT-PCR. According to the GUS analysis and the Root Visualization Expression Map, PLL19 is clearly expressed in uninfected roots. However, in contrast to GeneChip analysis, the qRT-PCR revealed lower expression levels in the root segments containing syncytia. This could be explained with a rather low expression level in cells surrounding the syncytium, which would lead to a kind of dilution effect of the high expression level in syncytia. Indeed, in situ RT-PCR showed only very weak expression of PLL19 in the root tissue adjacent to the syncytium. Summarizing, our data show that both genes are upregulated within syncytia whereas, in the cells adjacent to the syncytium, only PLL18 is upregulated.

The qRT-PCR analysis performed by Jammes and associates (2005) of roots infected with $M$. incognita showed that expression fold changes were generally lower than the ones obtained for syncytia. Moreover, transcriptome analysis of microdissected giant cells revealed that expression of PLL18 and PLL19 does not differ between 3-dai giant cells and surrounding gall tissue (Barcala et al. 2009). In the present study, these transcriptome results were confirmed by in situ RT-PCR carried out on sections of galls induced by $M$. incognita at 14 dai. There are several examples of other genes coding for cell wall-modifying enzymes that are either expressed exclusively within the nematode feeding site or in cells around the feeding sites in roots infected by both cyst and root-knot nematodes. Such specific expression patterns were previously shown for PAE (Vercauteren et al. 2002), XTR6 (a xyloglucan transferase from Arabidopsis) (Barcala et al. 2009), LeEXP4 (Fudali et al. 2008), LeEXPA5 (Bar-Or et al. 2005; Fudali et al. 2008; Gal et al. 2006), Arabidopsis expansins (Wieczorek et al. 2006), and extensins (Niebel et al. 1993). These examples indicate that differences in gene expression patterns might reflect distinct functions of these enzymes in different nematode-infected tissues. Similarly, based on the results for PLL18 and PLL19, one might speculate that, in roots infected by $H$. schachtii, both encoded enzymes could have similar roles within the feeding
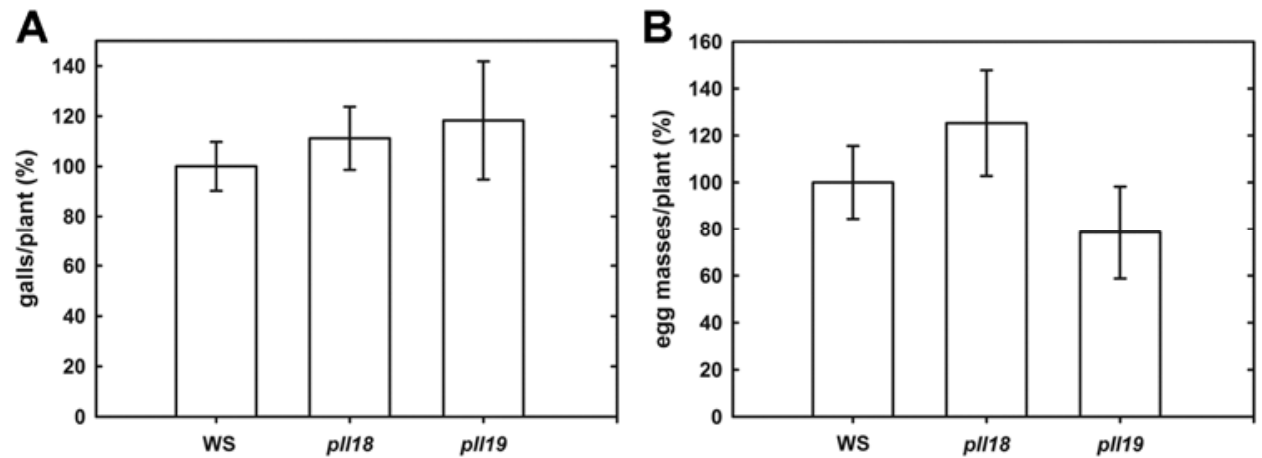

Fig. 7. Infection assay with Meloidogyne incognita. A, Relative number (\%) of galls per plant in roots of WS, pll18, and pll19 lines. B, Relative number (\%) of egg masses per plant produced in roots of WS, pll18, and pll19. Error bars show the standard errors from the mean $(n=3,30$ plants per replicate); $P<$ 0.05 versus control by analysis of variance. 
site, where they most probably participate in the modification and digestion of the syncytial walls. In the adjacent tissue, however, only expression of PLL18 is upregulated, suggesting that PLL18 might be involved in cell wall disassembly or relaxation and enlargement of cells that are being incorporated into the growing feeding site. This mediates syncytium expansion and development of conductive tissues, as formation of the feeding site triggers differentiation of new vascular elements (Golinowski et al. 1996).
Both PLL are important for cyst nematode development because mutants for both genes supported significantly fewer female nematodes than wild-type plants. In addition, on both mutant lines more retarded and small cysts were present and the number of intermediate sized and large cysts was decreased when compared with wild-type plants. Moreover, syncytia in the pll19 but not in the pll18 mutant were significantly shorter than in wild-type roots, which correlates with differences in tissue-specific expression of PLL18 and PLL19 and might
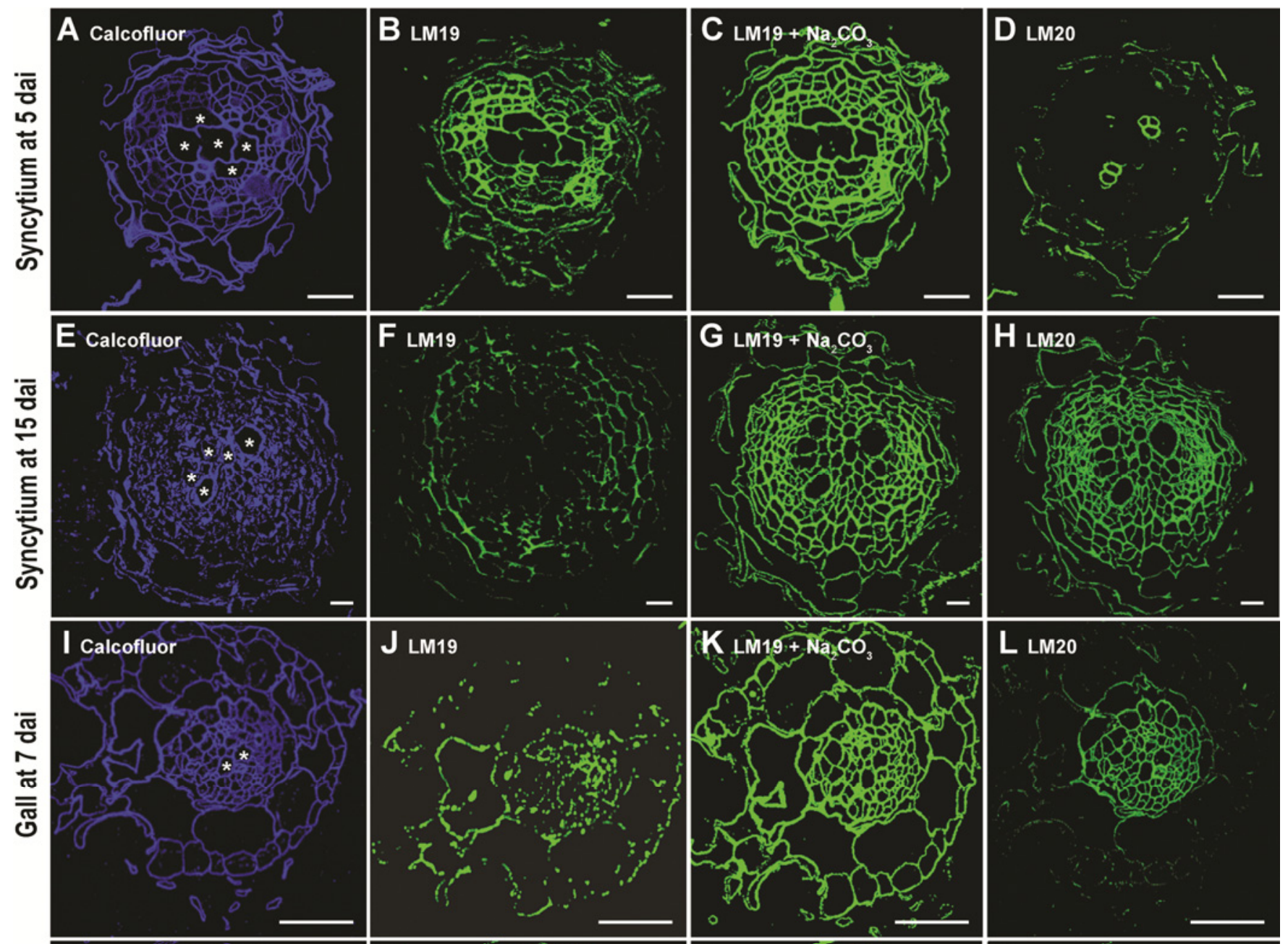

L LM20
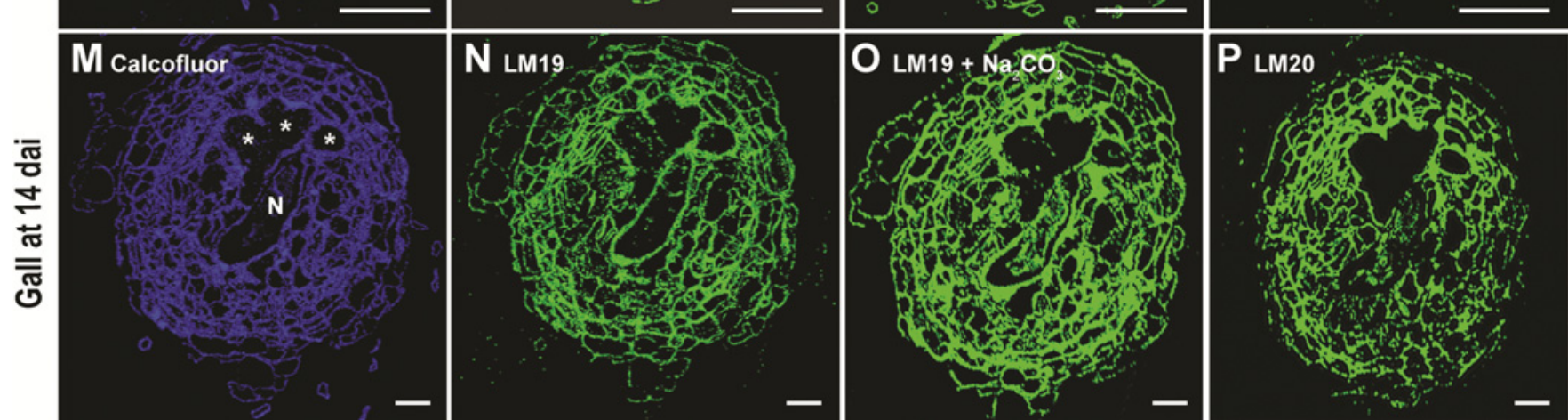

Fig. 8. Immunolabeling of pectin homogalacturonan (HG) in section of syncytia induced by Heterodera schachtii at 5 and 15 days after inoculation (dai); and galls induced by Meloidogyne incognita at 7 and 14 dai. A, Calcofluor-stained section of 5-dai syncytium. B, The LM19 antibody recognizes the unesterified HG in 5-dai syncytia. C, The LM19 antibody recognizes the unesterified HG in 5-dai syncytia after $\mathrm{Na}_{2} \mathrm{CO}_{3}$ pretreatment. D, The LM20 localizes the methyl-esterified HG in 5-dai syncytia. E, Calcofluor-stained section of 15-dai syncytium. F, Lack of LM19 signal in syncytial cell walls at 15 dai. G, The LM19 antibody recognizes the unesterified $\mathrm{HG}$ in syncytial cell walls at 15 dai after $\mathrm{Na}_{2} \mathrm{CO}_{3}$ pretreatment. $\mathbf{H}$, LM20 bounds to syncytial cell walls at 15 dai. I, Calcofluor-stained section of 7-dai gall. J, The LM19 antibody recognizes the unesterified HG in 7-dai galls. K, The LM19 antibody recognizes the unesterified $\mathrm{HG}$ in 7-dai galls after $\mathrm{Na}_{2} \mathrm{CO}_{3}$ pretreatment. $\mathbf{L}$, The LM20 localizes the methyl-esterified $\mathrm{HG}$ in 7-dai galls. M, Calcofluor-stained section of 14-dai gall. N, The LM19 antibody recognizes the unesterified HG in 14-dai galls. Sections were additionally treated with $\mathrm{Na}_{2} \mathrm{CO}_{3}$ prior immunolabeling with LM19 to remove methyl groups from HG. O, The LM19 antibody recognizes the unesterified HG in 14-dai galls after $\mathrm{Na}_{2} \mathrm{CO}_{3}$ pretreatment. $\mathbf{P}$, The LM20 localizes the methyl-esterified HG in 14-dai syncytia. Each figure is a representative of three independent sections. Bars $=50 \mu \mathrm{m}$. 
point at their different roles in the formation of the feeding site. Thus, absence of PLL19 activity in the syncytium might hamper incorporation of new cells into the growing syncytium.

In feeding sites induced by $M$. incognita, both genes are upregulated. However, there was no difference between the expression in giant cells and the remaining gall tissue. Moreover, infection tests did not reveal any differences in susceptibility between both mutants and the wild type. This suggests that both PLL are either not essential for the development of giant cells and gall tissue or that both have the same function and could rescue each other in the respective mutant. There also might be redundancy with other genes within the large $P L L$ family in Arabidopsis. The extensive overlap in the promoter activity of many PLL (Sun and van Nocker 2010) corroborates this assumption.

The observed differences in the susceptibility of the mutants toward $H$. schachtii or $M$. incognita might be based predominantly on the distinct ontogenesis of syncytia and giant cells. The first ones are formed via cell wall dissolution and fusion of the root cells (Jones and Dropkin 1975). During their development, the walls have to be digested as well as specifically modified, which enables their extension, thickening, and strengthening. In contrast, giant cells grow without fusion of additional root cells and several giant cells arise from single vascular parenchyma cells via repeated nuclear division without complete cytokinesis (Caillaud et al. 2008). Their cell walls expand and are thickened without being digested (Abad et al. 2003), involving a different set of cell wall-modifying enzymes.

It was recently shown that cell walls of syncytia at 14 dai induced by $H$. schachtii are rich in the highly esterified form of pectic HG (Davies et al. 2012), a result that we confirmed here. These authors used only mature syncytia. Therefore, we performed immunohistochemistry on younger syncytial cell walls at 5 dai as well as cell walls of giant cells induced by $M$. incognita at 7 and 14 dai. Our results indicated larger amounts of unmethylated HG in cell walls of syncytia at 5 dai as compared with 14 dai. Several reports showed, for example, a putative PAE to be specifically upregulated in root tissue infected with cyst and root-knot nematodes (Vercauteren et al. 2002) or an Arabidopsis PME3 which is targeted and activated by a cellulose-binding protein secreted by $H$. schachtii during the sedentary stage (Hewezi et al. 2008). These esterases would be a prerequisite for the activity of PLL, which can only degrade unmethylated pectin. Therefore, the upregulation of PLL18 and PLL19 is necessary for digestion of pectin and other cell wall polysaccharides, which is important for growth of the syncytium.

In contrast to young syncytia, in mature feeding sites, the incorporation of new cells into the feeding site does not occur any longer and syncytial walls only expand and thicken in order to withstand the turgor pressure. For this purpose, pectin has to be mainly synthetized de novo. The high methyl ester status of HG in older syncytia could contribute to the capacity for extension and flexibility of cell walls, as previously suggested by Davies and associates (2012). We showed here that, at this time, both $P L L$ are still expressed at high levels. Thus, the low level of unmethylated HG in older syncytia could be explained by digestion driven by these enzymes. Further, the elevated PLL expression might be connected to the still ongoing digestion of cell wall stubs and fragments inside the syncytium.

In contrast to syncytia, 7-dai galls and walls of giant cells had elevated levels of highly methylated pectin, whereas the levels of unmethylated HG were rather low. This corresponds to a rather low expression of both $P L L$ at this time. The reason for the presence of highly methylated $\mathrm{HG}$ in cell walls of giant cells could be a lack of cell wall digestion which, in syncytia, is a prerequisite for the fusion of syncytial elements. Synthesis of new pectin is needed to enable walls of giant cells to expand and thicken. Probably a similar situation can be observed in the parenchyma cells surrounding the giant cells that undergo hyperplasia and hypertrophy, forming a typical gall. This also might be a reason for the detection of methyl-esterified pectin in those cells. In contrast to young galls, at 14 dai in cell walls of giant cells, we detected slightly larger amounts of unmethylesterified $\mathrm{HG}$, which contributes to cell wall strength. This is in line with the increased expression of both PLL in giant cells at this time.

In conclusion, our results indicate that developmental mechanisms regarding pectin and its role during the formation of syncytia and giant cells or galls differ significantly. We showed that different degrees of methyl-esterification of $\mathrm{HG}$ reflect the morphological differences between these two feeding sites as well as time-dependent alteration of the syncytial cell wall. Further, the expression and localization studies of PLL18 and PLL19 presented here as well as functional testing of mutants show that both $P L L$ are more important for the parasitism of $H$. schachtii than for $M$. incognita development and the formation of giant cells and gall tissue. This comparative study not only sheds light on important cell wall processes in different nematode feeding sites but also expands our knowledge of the interaction between plant-parasitic nematodes and their host plants, which could be utilized in various resistance breeding strategies.

\section{MATERIALS AND METHODS}

\section{Plant cultivation.}

Arabidopsis seed were surface-sterilized for $10 \mathrm{~min}$ in $5 \%$ (wt/vol) calcium hypochlorite, submerged for $5 \mathrm{~min}$ in $70 \%$ (vol/vol) ethanol, and subsequently washed three times in sterile distilled $\mathrm{H}_{2} \mathrm{O}$. Ten sterilized seed were placed into sterile petri dishes $(9 \mathrm{~cm}$ in diameter) on a modified 0.2 concentrated Knop medium supplemented with $2 \%$ sucrose (Sijmons et al. 1991). Petri dishes were then transferred to a growth chamber at $24^{\circ} \mathrm{C}$ with a $16 \mathrm{~h}$ photoperiod.

\section{Isolation of DNA and RNA from Arabidopsis.}

Isolation of genomic DNA from leaves of Arabidopsis (ecotype WS) was done according to the method of Gustincich and associates (1991) as modified by Clark and associates (1997). Total RNA was isolated using an RNeasy plant mini kit (Qiagen, Hilden, Germany) according to the manufacturer's instructions, including DNA digestion with DNaseI. Genomic DNA was isolated from young leaves, whereas RNA was obtained from complete shoots and roots of uninfected 21-day-old Arabidopsis plants as well as infected root segments containing 5and 15-dai syncytia induced by $H$. schachtii and 7- and 14-dai galls induced by $M$. incognita.

\section{Nematode stock culture and infection assay.}

Cysts of $H$. schachtii were harvested from in vitro stock cultures on mustard roots (Sinapsis alba 'Albatros') growing on 0.2 concentrated Knop medium supplemented with $2 \%$ sucrose (Sijmons et al. 1991). Hatching of juveniles was stimulated by soaking cysts in $3 \mathrm{mM} \mathrm{ZnCl}$. The juveniles were washed four times in sterile $\mathrm{H}_{2} \mathrm{O}$ and resuspended in $0.5 \%$ (wt/vol) Gelrite (Duchefa, Haarlem, The Netherlands) prior to inoculation. Before inoculation with $H$. schachtii, total root length of each line was estimated as described by Jürgensen (2001). For infection assays, 10 Arabidopsis plants/plate were grown under sterile conditions and, after 12 days, inoculated with batches of approximately 50 freshly hatched juveniles/plant. After 2 weeks, 
the total number of females and males was counted and the male/female ratio was calculated. Experiments were repeated three times (average number of plants/experiment: $\mathrm{WS}=64$, pll18 $=48$, and pll19 $=23$ ) and the significance of the results was determined statistically by analysis of variance (ANOVA) $(P<0.05)$ (SPSS 12.0; SPSS Inc., Chicago).

After 4 weeks, the length of syncytia and the size of cysts were measured using an inverted microscope (Axiovert 200M; Zeiss, Hallerbergmoos, Germany) with an integrated camera (AxioCam MRc5; Zeiss) and AxioVision software (number of measured syncytia and cysts: $\mathrm{WS}=74$, pll18 $=38$, and pll19= 62).

For M. incognita infection, Arabidopsis plants were grown in vitro on Murashige Skoog (MS) medium containing 1\% sucrose and $0.7 \%$ plant cell culture-tested agar (Sigma-Aldrich, St. Louis). For sterilization, freshly hatched $M$. incognita second-stage juveniles were placed on a sterile Swinnex filter holder with a cellulose nitrate membrane (pore size $=3 \mu \mathrm{m}$; Millipore, Bedford, MA, U.S.A.). Nematodes were exposed to $0.01 \% \mathrm{HgCl}_{2}$ for $10 \mathrm{~min}$, then washed once with $0.7 \%$ streptomycin and four times with sterile water. In all, 200 surfacesterilized nematodes per 2-week-old seedling were used. The plates were kept at $20^{\circ} \mathrm{C}$ with a 16 -h photoperiod. Galls and egg masses were counted 8 weeks following infection.

\section{PLL promoter::GUS and mutant lines.}

PromPLL18:GUS was originally described by Sun and van Nocker (2010). For PromPLL19:GUS fusion, a fragment of $1 \mathrm{~kb}$ upstream of the start codon was amplified by PCR using the primers PLL19_P5GW (5'-AAA AAG CAG GCT TCC CCA CTT GAT GCA TAA AGA ATG-3') and PLL19_P3GW (5'AGA AAG CTG GGT GTG TTC TCT CTC TCT CTC ACT TG-3'). The PCR fragment was inserted into the pDON207 donor vector and then in the plant expression vectors pKGWFS7 using Gateway Technology (Invitrogen, Carlsbad, CA, U.S.A.). This construct was sequenced and transformed into Agrobacterium tumefaciens GV3101. Wild-type Arabidopsis WS plants were transformed using the dipping method (Clough and Bent 1998) and selected on MS medium $0.7 \%$ agar plates containing kanamycin at $50 \mu \mathrm{g} / \mathrm{ml}$. Transformed plants were transferred to soil and seed were collected. Five independent T1 transformants were selected by PCR, T2 and T3 plants were obtained, and one representative line was used for GUS analysis.

We obtained two mutants with insertions in PPL18 and PLL19 in WS background from INRA Versailles. We characterized the insertion site by sequencing the genomic regions flanking the inserted T-DNA, as described by Caillaud and associates (2008). The pll18 (EHH76) and pll19 (EXQ26) lines carried a single T-DNA insert. These lines presented a 3:1 segregation of the kanamycin marker carried by the T-DNA. The T-DNA had integrated into the PLL18 promoter, $261 \mathrm{bp}$ upstream of the transcription initiation site or into the PLL19 promoter, $355 \mathrm{bp}$ upstream of the transcription initiation site, respectively (Fig. 3A). To isolate homozygous pll18/pll18 and pll19/pll19 plants, we analyzed the segregation of the kanamycin marker carried by the T-DNA on progenies resulting from each of 20 plants. Progenies of five plants segregated $100 \%$ kanamycin-resistant plants, indicating that they were homozygous for the T-DNA tagged allele. To confirm this result, PCR experiments were done with PLL primers (PLL18_P5, 5'-AAG TGG TCA CAA AGG ATT GCT-3' and PLL18_P3, 5'-TCT TCT AAA CAT AGA TTG A-3' or PLL19_P5 5'-CCC ACT TGA TGC ATA AAG AAT G-3' and PLL19_P3, 5'-TTC TCT CTC TCT CTC ACT TG-3') which span the T-DNA insertion site, and a third primer TAG5 (5'-CTA CAA ATT GCC TTT TCT TAT CGA C-3') specific for the sequence of the T-DNA. Phenotypic analysis of pll18 and pll19 mutants was always performed in comparison with wild-type plants of the same genetic background (WS). We analyzed rosette area and root length of 23, 24, and 29 single pll18, pll19, and WS 10-dayold seedlings, respectively. The counting of lateral roots was performed on 15-day-old WS, pll18, and pll19 plants. All phenotypical measurements were analyzed statistically by ANOVA $(P<0.05)$ (SPSS 12.0; SPSS Inc.).

\section{GUS assay.}

Detection of GUS activity was performed according to the histochemical method of Schrammeijer and associates (1990) using a solution of $2 \mathrm{mM}$ 5-bromo-4-chloro-3-indolyl-b-D-glucuronic acid (X-gluc; Biomol, Hamburg, Germany) in $0.1 \mathrm{M}$ sodium phosphate buffer $(\mathrm{pH} 7.0)$ supplemented with $0.1 \%$ Triton-X 100, $0.5 \mathrm{mM} \mathrm{K}_{3}\left[\mathrm{Fe}(\mathrm{CN})_{6}\right], 0.5 \mathrm{mM} \mathrm{K}_{4}\left[\mathrm{Fe}(\mathrm{CN})_{6}\right]$, and $10 \mathrm{mM} \mathrm{Na}{ }_{2}$ EDTA. Plants were covered with freshly prepared $\mathrm{X}$-gluc solution and incubated overnight at $37^{\circ} \mathrm{C}$. After staining, chlorophyll was extracted from photosynthetic tissues with $70 \%$ (vol/vol) ethanol. The GUS activity was detected microscopically by the distinct blue coloration resulting from the enzymatic cleavage of X-gluc.

\section{qRT-PCR.}

Concentration of RNA was quantified using an Agilent 2100 bioanalyzer (Agilent Technologies, Palo Alto, CA, U.S.A.). Reverse transcription was performed with the SuperScript III kit (Invitrogen, Carlsbad, CA, U.S.A.) using random primers. The relative change in expression levels of synthesized transcripts was measured using the 7300 Real Time PCR System (Applied Biosystems, Foster City, CA, U.S.A.). 18S RNA and UBP22 were used as endogenous controls (Hofmann and Grundler 2007). qRT-PCR was carried out using the following primers: PLL18 forward (5'-GCG GTG GCG ATA TTT GGA GGG AA-3') and reverse (5'-GCC TGC ACC GTG GAT TCT TTT-3'), and PLL19 forward (5'-GTT CAC AAG AGC ATT AAT GCG TCG GT-3') and reverse (5'-ACG GCC ACC GAT GGC GTT TT-3'). The efficiencies of primers were tested by standard quantification, using standard curves of four template dilutions and based on three separate replicates. Changes in expression were calculated according to the $2^{-\Delta \Delta C t}$ method (Livak and Schmittgen 2001).

\section{In situ RT-PCR.}

In situ RT-PCR was done according to Koltai and Bird (2000) and Urbanczyk-Wochniak and associates (2002). Syncytia induced by $H$. schachtii at $15 \mathrm{dpi}$ and galls induced by $M$. incognita at 14 dai were dissected from roots and immediately put into cold fixation solution (63\% ethanol [vol/vol] and $2 \%$ formalin [vol/vol]). After $24 \mathrm{~h}$, syncytia were embedded in $4 \%$ low-melting agarose and $25-\mu \mathrm{m}$-thick sections were prepared using a vibratome (VT 100; Leica, Wetzlar, Germany). RTPCR was then carried out using digoxigenin-labeled dUTP and primers used for qRT-PCR (see above). After a staining reaction with nitro blue tetrazolium/5-bromo-4-chloro-3-indolyl phosphate (Sigma-Aldrich), cross-sections were photographed under an inverted microscope (Axiovert 200M; Zeiss) with an integrated camera (AxioCam MRc5; Zeiss). For full details, see Wieczorek and associates (2006).

\section{Immunochemistry.}

Dissected root sections containing $H$. schachtii syncytia at 5 and 15 dai and $M$. incognita galls at 7 and 14 dai were fixed in the freshly prepared paraformaldehyde-glutaraldehyde fixative (50 $\mathrm{ml}$ of $0.2 \mathrm{M}$ phosphate buffer [pH 7], $20 \mathrm{ml}$ of $10 \%$ paraformaldehyde (Roth, Karlsruhe, Germany), $10 \mathrm{ml}$ of $25 \%$ glutaraldehyde (Sigma-Aldrich), and $20 \mathrm{ml}$ of $\mathrm{H}_{2} \mathrm{O}$ ). To improve the fixation, vacuum was applied for $15 \mathrm{~min}$. Samples were 
then incubated in $1 \mathrm{ml}$ of fixative overnight at $4^{\circ} \mathrm{C}$. Next-day samples were washed three times for $20 \mathrm{~min}$ in $0.1 \mathrm{M}$ phosphate buffer ( $\mathrm{pH} 7)$ and subsequently dehydrated for $20 \mathrm{~min}$ at $4^{\circ} \mathrm{C}$ in $30,50,70,80,90$, and $100 \%$ ethanol each. LR White (Sigma-Aldrich) was applied to each sample twice $\left(3 \mathrm{~h}\right.$ at $\left.4{ }^{\circ} \mathrm{C}\right)$ to ensure proper penetration of the sample. Subsequently, samples were put in resin-filled gelatine capsules and incubated for $24 \mathrm{~h}$ at $60^{\circ} \mathrm{C}$. Transverse sections $(1 \mu \mathrm{m}$ thick $)$ were prepared with the ultramicrotom (Leica Ultracut R; Leica) and mounted onto 12-well glass microscope slides coated with Teflon/silane (Tekdon, Myakka City, FL, U.S.A.). Control sections were incubated in $0.1 \mathrm{M} \mathrm{Na}_{2} \mathrm{CO}_{3}$ (pH 11.4) for $1.5 \mathrm{~h}$ to remove methyl esters that may mask specific epitopes. Subsequently, sections were washed three times with deionized water. Slides were than blocked with $3 \%$ (wt/vol) bovine serum albumen (BSA) in phosphate-buffered saline (PBS) buffer for $2 \mathrm{~h}$ at room temperature. After blocking, sections were incubated in fivefold diluted primary antibody (LM19 and LM20) (Verhertbruggen et al. 2009) in PBS containing 3\% BSA for 2 $\mathrm{h}$ at room temperature. After three washes in PBS, the sections were incubated with anti-rat immunoglobulin $\mathrm{G}$ linked to fluorescein isothiocyanate (Sigma-Aldrich) diluted 100-fold in PBS for $1.5 \mathrm{~h}$ in the dark. Following antibody treatment, all sections were washed three times in PBS before 5 min of incubation in Calcofluor (Sigma-Aldrich) at $1 \mathrm{mg} \mathrm{ml}^{-1}$ in the dark. Following several washes in PBS, sections were mounted in Fluoromount Aqueous Mounting Medium (Sigma-Aldrich) and were examined under a confocal laser-scanning microscope (FV1000; Olympus, Tokyo).

\section{ACKNOWLEDGMENTS}

The T-DNA lines were generated at and obtained from the INRA-Versailles Genomic Resource Center, France. The PromPLL18::GUS line was kindly provided by S. van Nocker (Department of Horticulture, Michigan State University, East Lansing). K. Wieczorek was supported by grant P21067-B12 (Austrian Science Fund). H. Bohlmann was supported by grant P20471-B11 (Austrian Science Fund). B. Favery and M. Quentin were supported by INRA and UNS. G. J. Seifert is supported by P21782 and I1182 (Austrian Science Fund). K. Wieczorek thanks L. Davies (Centre for Plant Sciences, University of Leeds, Leeds, West Yorkshire LS2 9JT, U.K.) for help in completing this work; and we thank P. Knox for the generous gift of monoclonal pectin antibodies.

\section{LITERATURE CITED}

Abad, P., Favery, B., Rosso, M. N., and Castagnone-Sereno P. 2003. Rootknot nematode parasitism and host response: Molecular basis of a sophisticated interaction. Mol. Plant Pathol. 4:217-224.

Atkinson, H. J., Urwin, P. E., Clarke, M. C., McPherson, and M. J. 1996. Image analysis of the growth of Globodera pallida and Meloidogyne incognita on transgenic tomato roots expressing cystatins. J. Nematol. 28:209-215

Atmodjo, M. A., Hao, Z., and Mohnen, D. 2013. Evolving views of pectin biosynthesis. Annu. Rev. Plant Biol. 64:747-779.

Barcala, M., García, A., Cabrera, J., Casson, S., Lindsey, K., Favery, B., García-Casado, G., Solano, R., Fenoll, C., and Escobar, C. 2009. Early transcriptomic events in microdissected Arabidopsis nematode-induced giant cells. Plant J. 61:698-712.

Bar-Or, C., Kapulnik, Y., and Koltai, H. 2005. A broad characterization of the transcriptional profile of the compatible tomato response to the plant parasitic root knot nematode Meloidogyne javanica. Eur. J. Plant Pathol. 111:181-192.

Barthels, N., van der Lee, F. M., Klap, J. Goddijn, O. J., Karimi, M., Puzio, P., Grundler, F. M., Ohl, S. A., Lindsey, K., Robertson, L., Robertson, W. M., Van Montagu, M., Gheysen, G., and Sijmons, P. C. 1997. Regulatory sequences of Arabidopsis drive reporter gene expression in nematode feeding structures. Plant Cell 9:2119-2134.

Bird, D. M., and Kaloshian, I. 2003. Are roots special? Nematodes have their say. Physiol. Mol. Plant Pathol. 62:115-123.

Caffall, K. H., and Mohnen, D. 2009. The structure, function, and biosynthesis of plant cell wall pectic polysaccharides. Carbohydr. Res. 344:1879-1900.
Cai, S., and Lashbrook, C. C. 2008. Stamen abscission zone transcriptome profiling reveals new candidates for abscission control: Enhanced retention of floral organs in transgenic plants overexpressing Arabidopsis ZINC FINGER PROTEIN2. Plant Physiol. 146:1305-1321.

Caillaud, M. C., Lecomte, P., Jammes, F., Quentin, M., Pagnotta, S., Andrio, E., de Almeida Engler, J., Marfaing, N., Gounon, P., Abad, P., and Favery, B. 2008. MAP65-3 microtubule-associated protein is essential for nematode-induced giant cell ontogenesis in Arabidopsis. Plant Cell 20:423-437.

Clark, A. M., Jacobsen, K. R., Dannenhoffer, J. M., Skaggs, and M. I., Thompson, G. A. 1997. Molecular characterisation of a phloemspecific gene encoding the filament protein, phloem protein 1 (PP1), from $\mathrm{Cu}$ curbita maxima. Plant J. 12:49-61.

Clough, S. J., and Bent, A. F. 1998. Floral dip: A simplified method for Agrobacterium-mediated transformation of Arabidopsis thaliana. Plant J. 16:735-743.

Danchin, E. G., Rosso, M. N., Vieira, P., de Almeida-Engler, J., Coutinho, P. M., Henrissat, B., and Abad, P. 2010. Multiple lateral gene transfers and duplications have promoted plant parasitism ability in nematodes. Proc. Natl. Acad. Sci. U.S.A. 107:17651-17656.

Davies, L. J., Lilley, C. J., Knox, P. J., and Urwin, P. E. 2012. Syncytia formed by adult female Heterodera schachtii in Arabidopsis thaliana roots have a distinct cell wall molecular architecture. New Phytol. 196:238-246.

Davis, E. L., Haegeman, A., and Kikuchi, T. 2011. Degradation of the Plant Cell Wall by Nematodes. Pages 255-272 in: Genomics and Molecular Genetics of Plant-Nematode Interactions. J. Jones, G. Gheysen, and C. Fenoll, eds. Springer, Dordrecht, The Netherlands.

Doyle, E. A., and Lambert, K. N. 2002. Cloning and characterization of an esophageal-gland-specific pectate lyase from the root-knot nematode Meloidogyne javanica. Mol. Plant-Microbe Interact. 15:549-556.

Fudali, S., Janakowski, S., Sobczak, M., Griesser, M., Grundler, F. M. W., and Golinowski, W. 2008. Two tomato $\alpha$-expansins show distinct spatial and temporal expression patterns during development of nematodeinduced syncytia. Physiol. Plant. 132:370-383.

Gal, T. Z., Aussenberg, E. R., Burdman, S., Kapulnik, Y., and Koltai, H. 2006. Expression of a plant expansin is involved in the establishment of root knot nematode parasitism in tomato. Planta 224:155-162.

Goellner, M., Wang, X., and Davis, E. L. 2001. Endo-beta-1,4-glucanase expression in compatible plant-nematode interactions. Plant Cell 13:2241-2255.

Golinowski, W., Grundler, F. M. W., and Sobczak, M. 1996. Changes in the structure of Arabidopsis thaliana induced during development of females of the plant parasitic nematode Heterodera schachtii. Protoplasma 194:103-116.

Gustincich, S., Manfioletti, G., del Sal, G., and Schneider, C. 1991. A fast method for high quality genomic DNA extraction from whole human blood. BioTechniques 11:298-302.

Hewezi, T., and Baum, T. J. 2012. Manipulation of plant cells by cyst and root-knot nematode effectors. Mol. Plant-Microbe Interact. 26:9-16.

Hewezi, T., Howe, P. J., Maier, T. R., Hussey, R. S., Mitchum, M. G., Davis, E. L., and Baum, T. J. 2008. Cellulose binding protein from the parasitic nematode Heterodera schachtii interacts with Arabidopsis pectin methylesterase: Cooperative cell wall modification during parasitism. Plant Cell 20:3080-3093.

Hofmann, J., and Grundler, F. M. W. 2007. Identification of reference genes for qRT-PCR studies of gene expression in giant cells and syncytia induced in Arabidopsis thaliana by Meloidogyne incognita and Heterodera schachtii. Nematology 9:317-323.

Huang, G., Dong, R., Allen, R., Davis, E. L., Baum, T. J., and Hussey, R. S. 2005. Developmental expression and molecular analysis of two Meloidogyne incognita pectate lyase genes. Int. J. Parasitol. 35:685692.

Hudson, L. C. 2008. Analysis of cell wall synthesis genes in feeding cells formed by root-knot nematodes. Ph.D. thesis, Plant Pathology, North Carolina State University, Raleigh.

Jammes, F., Lecomte, P., Almeida-Engler, J., Bitton, F., Martin-Magniette, M. L., Renou, J. P., Abad, P., and Favery, B. 2005. Genome-wide expression profiling of the host response to root-knot nematode infection in Arabidopsis. Plant J. 44:447-458.

Jones, M. G. K., and Dropkin, V. H. 1975. Scanning electron microscopy of syncytial transfer cells induced in roots by cyst nematodes. Physiol. Plant Pathol. 7:259-263.

Jürgensen, K. 2001. Untersuchungen zum Assimilat- und Wassertransfer in der Interaktion zwischen Arabidopsis thaliana and Heterodera schachtii. Ph.D. thesis, Agrar- und Ernährungswissenschaftlichen Fakultät, Christian-Albrecht Universität, Germany.

Koltai, H., and Bird, D. M. 2000. High throughput cellular localization of specific plant mRNAs by liquid-phase in situ reverse transcription-polymerase chain reaction of tissue sections. Plant Physiol. 123:1203-1212. 
Knox, J. P. 2002. Cell and developmental biology of pectins. Pages 131146 in: Pectins and Their Manipulation. G. B. Seymour, and J.P. Knox, eds. Blackwell Publishing, Oxford.

Kudla, U., Milac, A. L., Qin, L., Overmars, H., Roze, E., Holterman, M., Petrescu, A. J., Goverse, A., Bakker, J., Helder, J., and Smant, G. 2007. Structural and functional characterization of a novel, host penetrationrelated pectate lyase from the potato cyst nematode Globodera rostochiensis. Mol. Plant Pathol. 8:293-305.

Livak, K. J., and Schmittgen, T. D. 2001. Analysis of relative gene expression data using real-time quantitative PCR and the $2^{-\Delta \Delta \mathrm{Ct}}$ method. Methods 25:402-408.

McNeil, M., Darvill, A. G., Fry, S. C., and Albersheim, P. 1984. Structure and function of the primary cell wall of plants. Annu. Rev. Biochem. 53:625-663.

Mitchum, M. G., Sukno, S., Wang, X., Shani, Z., Tsabary, G., Shoseyov, O., and Davis, E. 2004. The promoter of the Arabidopsis thaliana cel1 endo-1,4- $\beta$-glucanase gene is differentially expressed on plant feeding cells induced by root-knot and cyst nematode. Mol. Plant Pathol. 5:175181

Niebel, A., de Almeida-Engler, J., Tiré, C., Engler, G., van Montagu, M., and Gheysen, G. 1993. Induction patterns of an extensin gene in tobacco upon nematode infection. Plant Cell 5:1697-1710.

Palusa, S. G., Golovkin, M., Shin, S. B., Richardson, D. N., and Reddy, A. S. 2007. Organ-specific, developmental, hormonal and stress regulation of expression of putative pectate lyase genes in Arabidopsis. New Phytol. 174:537-550

Payasi, A, Sanwal, R., and Sanwal, G. G. 2009. Microbial pectate lyases: Characterization and enzymological properties. World J. Microbiol. Biotechnol. 25:1-14.

Popeijus, H., Overmars, H., Jones, J., Blok, V., Goverse, A., Helder, J., Schots, A., Bakker, J., and Smant, G. 2000. Degradation of plant cell walls by a nematode. Nature 406:36-37.

Puzio, P., Cai, D., Ohl, S., Wyss, U., and Grundler, F. M. W. 1998. Isolation of regulatory DNA region related to differentiation of nematode feeding structure in Arabidopsis thaliana. Physiol. Mol. Plant Pathol. 53:177-193.

Rosso, M. N., Favery, B., Piotte, C., Arthaud, L., De Boer, J. M., Hussey, R. S., Bakker, J., Baum, T. J., and Abad, P. 1999. Isolation of a cDNA encoding a $\beta-1,4$-endoglucanase in the root-knot nematode Meloidogyne incognita and expression analysis during plant parasitism. Mol. Plant-Microbe Interact. 12:585-591.

Schrammeijer, P. C., Sijmons, P. C., van den Elzen, P. J. M., and Hoekema, A. 1990. Meristem transformation of sunflower via Agrobacterium. Plant Cell Rep. 9:55-60.

Siddique, S., Sobczak, M., Tenhaken, R., Grundler, F. M. W., and Bohlmann, H. 2012. Cell wall ingrowths in nematode induced syncytia require UGD2 and UGD3. PLoS One 7:e41515.

Sijmons, P. C., Grundler, F. M. W., von Mende, N., Burrows, P. R., and Wyss, U. 1991. Arabidopsis thaliana as a new model host for plantparasitic nematodes. Plant J. 1:245-254.

Sobczak, M. 1996. Investigations on the structure of syncytia in roots of Arabidopsis induced by the beet cyst nematode $H$. schachtii and its relevance to the sex of the nematode. Ph.D. thesis, Christian-Albrecht Universität, Kiel, Germany.

Sobczak, M., Fudali, S., and Wieczorek, K. 2011. Cell wall modifications induced by nematodes. Page 557 in: Genomics and Molecular Genetics of Plant-Nematode Interactions. J. Jones, G. Gheysen, and C. Fenoll, eds. Springer, Dordrecht, The Netherlands.

Sukno, S., Shimerling, O., McCuiston, J., Tsabary, G., Shani, Z., Shoseyov, C., and Davis, E. L. 2006. Expression and regulation of the Arabidopsis thaliana cell endo 1,4 beta glucanase gene during compatible plant-nematode interactions. J. Nematol. 38:354-361.

Sun, L., and van Nocker, S. 2010. Analysis of promoter activity of members of the PECTATE LYASE-LIKE (PLL) gene family in cell separation in Arabidopsis. BMC Plant Biol. 10:152.

Swarup, K., Benková, E., Swarup, R., Casimiro, I., Péret, B., Yang, Y.,
Parry, G., Nielsen, E., Smet, I. D., Vanneste, S., Levesque, M. P., Carrier, D., James, N., Calvo, V., Ljung, K., Kramer, E., Roberts, R., Graham, N., Marillonnet, S., Patel, K., Jones, J. D. G., Taylor, C. G., Schachtman, D. P., Sandberg, G., Benfey, P., Friml, J., Kerr, I., Beeckman, T., Laplaze, L., and Bennett, M. J. 2008. The auxin influx carrier LAX3 promotes lateral root emergence. Nat. Cell Biol. 10:946954.

Szakasits, D., Heinen, P., Wieczorek, K., Hofmann, J., Wagner, F., Kreil, D. P., Sykacek, P., Grundler, F. M. W., and Bohlmann, H. 2009. The transcriptome of syncytia induced by the cyst nematode Heterodera schachtii in Arabidopsis roots. Plant J. 57:771-784.

Triantaphyllou, A. C. 1973. Environmental sex differentiation of nematodes in relation to pest management. Annu. Rev. Phytopathol. 11:44414462

Tucker, M. L., Burke, A., Murphy, C. A., Thai, V. K., and Ehrenfried, M. L. 2007. Gene expression profiles for cell wall-modifying proteins associated with soybean cyst nematode infection, petiole abscission, root tips, flowers, apical buds, and leaves. J. Exp. Bot. 58:3395-3406.

Urbanczyk-Wochniak, E., Filipecki, M., and Przybecki, Z. 2002. A useful protocol for in situ RT-PCR on plant tissues. Cell. Mol. Biol. Lett. 7:718 .

Vanholme, B., van Thuyne, W., Vanhouteghem, K., de Meutter, J., Cannoot, B., and Gheysen, G. 2007. Molecular characterization and functional importance of pectate lyase secreted by the cyst nematode Heterodera schachtii. Mol. Plant Pathol. 8:267-278.

Vercauteren, I., de Almeida Engler, J., de Groodt, R., and Gheysen, G. 2002. An Arabidopsis thaliana pectin acetylesterase gene is upregulated in nematode feeding sites induced by root-knot and cyst nematodes. Mol. Plant-Microbe Interact. 15:404-407.

Verhertbruggen, Y., Marcus, S. E., Haeger, A., Ordaz-Ortiz, J. J., and Knox, J. P. 2009. An extended set of monoclonal antibodies to pectic homogalacturonan. Carbohydr. Res. 344:1858-1862.

Vogel, J. P., Raab, T. K., Schiff, C., and Somerville, S. C. 2002. PMR6, a pectate lyase-like gene required for powdery mildew susceptibility in Arabidopsis. Plant Cell 14:2095-2106.

von Mende, N. 1997. Invasion and migration behavior of sedentary nematodes. Pages 51-64 in: Cellular and Molecular Aspects of Plant-Nematode Interactions. C. Fenoll, F. M. W. Grundler, and S. A. Ohl, eds. Kluwer Academic Publishers, Dordrecht, The Netherlands.

Wieczorek, K., Golecki B., Gerdes, L., Heinen, P., Szakasits, D., Durachko D. M., Cosgrove, D. J., Kreil, D. P., Puzio, P. S., Bohlmann, H., and Grundler, F. M. W. 2006. Expansins are involved in the formation of nematode-induced syncytia in roots of Arabidopsis thaliana. Plant J. 48:98-112.

Wieczorek, K., Hofmann, J., Blöchl, A., and Grundler, F. M. W. 2008. Expression of endo-1,4- $\beta$-glucanase gene family in syncytia induced by Heterodera schachtii. Plant J. 53:336-351.

Wyss, U. 1992. Observations on the feeding behavior of Heterodera schachtii throughout development, including events during moulting. Fundam. Appl. Nematol. 15:75-89.

Wyss, U., and Grundler, F. M. W. 1992. Heterodera schachtii and Arabidopsis thaliana, a model host-parasite interaction. Nematologica 38:488-493.

Wyss, U., and Zunke, U. 1986. Observations on the behaviour of second stage juveniles of Heterodera schachtii inside host roots. Rev. Nematol. 9:153-165.

Xie, F., Murray, J. D., Kim, J., Heckmann, A. B., Edwards, A., Oldroyd, G. E., and Downie, J. A. 2012. Legume pectate lyase required for root infection by rhizobia. Proc. Natl. Acad. Sci. U.S.A. 109:633-638.

\section{AUTHOR-RECOMMENDED INTERNET RESOURCES}

INRA-Versailles Genomic Resource Center, France: www-ijpb.versailles.inra.fr/en/index.htm

Root visualization expression map: bar.utoronto.ca/efp 